\title{
Identifying the underlying constructs linking urban form and travel behaviour using a grounded theory approach
}

\author{
U. Banerjee $\cdot$ J. Hine
}

Received: 16 December 2013/Revised: 7 March 2014/Accepted: 7 April 2014/Published online: 29 April 2014

(C) Islamic Azad University (IAU) 2014

\begin{abstract}
The role of urban form in influencing travel behaviour has gained particular interest to scholars and policy makers to achieve a broader goal of sustainability despite varied scholastic opinion on the effectiveness of this relationship. While transportation forms the nexus of any urban environment, it also accounts for about thirty-six per cent of the total energy consumption in the UK [Department of Energy and Climate Change, UK, 2013]. Thus, an emphasis to reduce greenhouse emissions in this sector remains a key policy objective to achieve sustainability. Also there is an overemphasis of research in this area on quantitative association between key variables as opposed to qualitative exploration in order to understand complex human behaviour. The study reported in this paper has been designed to address this gap. Using a grounded theory analysis, this paper reports findings from 6 focus group discussions and 17 in-depth interviews. Fifty-three participants were recruited from three case study areas across Northern Ireland to represent the urban continuum. Seven overarching categories have been identified explaining the interrelationships between urban form and travel behaviour in the Northern Ireland context. However, at a macro-scale, land-use policies have played a dominant role in shaping the travel patterns and this has translated in the form of car dependency and residential immobility over the years in Northern Ireland. Although current policy now adopts a more integrated approach to curb urban sprawl and achieve modal split, soft policy measures have proved useful in increasing the effectiveness of these policy interventions.
\end{abstract}

U. Banerjee $(\bowtie) \cdot$ J. Hine

School of the Built Environment, University of Ulster, Shore

Road, Newtownabbey, Belfast BT37 0QB, UK

e-mail: Banerjee-U@email.ulster.ac.uk
Keywords Urban form - Travel behaviour . Sustainability · Grounded theory · Policy intervention

\section{Introduction}

Since the emergence of new planning concepts such as the new urbanism, neo-traditional development in the USA and the concept of the 'compact city' in Europe, all designed to curb urban sprawl, the centre of focus has been reduction of automobile dependency for which researchers aim at evaluating the influence of the built environment on travel behaviour (Bohte et al. 2009; Cao et al. 2009; Banister 2008). The major factors that have been identified as having an influence on travel behaviour are the urban form elements (such as density, land-use mix, accessibility, network pattern and infrastructure), socio-economic conditions, demographical influences and personal preferences. However, these are not mutually exclusive factors and what remains less explored is the interaction between these objective and subjective factors resulting in the daily travel patterns.

Also the relationship between urban form and travel behaviour is of particular interest to scholars and policy makers to achieve the broader global goal of sustainable growth amidst current concerns for climate change to achieve a balance between economic and social development and environmental issues. The sustainability paradigm was initiated by the Brundtland report, to direct growth such that the current growth patterns do not have an adverse effect on the future generation (World Commission on Environment and Development 1987), followed by the Rio Earth summit in 1992 in which authorities were encouraged to adopt the recommendations of the Brundtland report to tackle environment degradation issues. The 
Kyoto Protocol to the United Nations Framework Convention on Climate Change (UNFCCC) in 1997 finally set the binding obligation to reduce greenhouse emissions and with the transport and land-use sector accounting for $24.3 \%$ of the total greenhouse gas emissions (Department of Energy and Climate Change 2013); any significant saving in this sector could account for overall reduction in greenhouse gas emissions. Thus, a basic need to reduce travel is pivotal and integrated approaches are sought in terms of policy to integrate transport with the environment, land-use planning, different modes of transport and policies for sustainable urban development as the majority of world population now live in urban areas in both developed and developing countries alike (Dur and Yigitcanlar 2014; Yigitcanlar and Teriman 2014).

The main concern in terms of research findings in this area lies in the lack of general consensus on the effect of urban form on travel behaviour with studies differing in opinion on the strength and the validity of this relationship. To take for example the most influential urban form indicators such as density, land use, neighbourhood structure, centrality and accessibility, there are studies both supporting and negating their influence on travel behaviour. In the UK context itself while some researchers argue on the effectiveness of urban planning tools such as density, accessibility and land use in managing travel demand (Banister 1996, 2007; Hickman and Banister 2007; Aditjandra et al. 2012), others argue that the socio-economic factors play a greater role in influencing travel behaviour (Gordon 2008; Stead 2001; Susilo et al. 2012; Aditjandra et al. 2009) and still some contend that a combination of socio-economic factors and attitudes influence travel behaviour (Aditjandra et al. 2013), thus not being able to clearly point out at what influences travel behaviour. Also there is a vast body of research which advocates the idea that using land use as a planning tool to influence the location of activities and creating diversity, travel-related energy can be reduced (Headicar 2003; Leck 2006; Maat et al. 2005) including some recent studies that have mentioned the usefulness of this tool to influence travel behaviour in the UK context (Aditjandra et al. 2012), while others report little or no effect of land use in explaining travel behaviour (Crane and Crepeau 1998). Instead attitudes were found to be more strongly associated with travel behaviour rather than land-use characteristics (Kitamura et al. 1997; Aditjandra 2013). Similar discrepancies in opinion on the validity and influence of neighbourhood structure and accessibility on travel behaviour can be found with studies reporting the effectiveness of better accessibility to public transport potentially reducing car travel (Maat et al. 2005) while others report little or no effect at all
(Crane and Crepeau 1998; Snellen et al. 2002). Similarly, there are studies which contend that the concept of centrality in the spatial setting of a city which is expressed in terms of distance to the city centre did play an important role in influencing travel behaviour and energy consumption (Hickman and Banister 2007; Naess 2003; Simma and Axhausen 2003; Naess 2011). Still others argue that the spatial context has no influence on travel behaviour, and other indicators such as density and psychological aspects play a greater role in explaining travel patterns (Timmermans et al. 2003). We can thus conclude that there is no consensus on the effect of urban form in influencing travel behaviour as the vast body of literature remains divided in opinion.

Also differing geographical locations have shown complete opposite urban residential location choice which impacts on the travel behaviour. For example in the UK, where the rise in socio-economic factors such as income and affordability leads to demand for more space, thus creating lower density and longer commuting patterns. Opposed to this in Europe, the rich would be occupying the central hub of the cities where as the lesser capable ones would be forced out (Gordon 2008). In comparison, a study in US reports opposite findings where the economically disadvantaged occupied the inner-city locations and were at a closer proximity to the job market in the physical context. Thus, commute trip length was negatively associated with the socio-economically disadvantaged (Antipova et al. 2011).

Thus, in general, we find that studies have shown a stronger association with the quantitative explanation of the relationship between urban form and travel behaviour to ascertain the strength of this relationship. Thus, while most studies have successfully established the association in quantitative measures the qualitative dimension remains less explored to clearly explain the 'how' and 'why' of this relationship which has been identified as an important area for further research to understand the complexities of travel behaviour (Clifton and Handy 2003; Handy 1996). This study is thus designed to address these concerns to fill in the gap left by quantitative studies.

\section{The study}

This study aims at exploring the interrelationship patterns between travel behaviour, urban form, socio-economic influences and personal preferences that are of significance in the Northern Ireland context. Thus, the overall aim of this study is to understand the rationale and mechanism of these interrelationships and identify the underlying constructs linking urban form and travel behaviour in the local context. Figure 1 shows the conceptual framework linking these factors. 
Fig. 1 Conceptual framework showing the interrelationship patterns

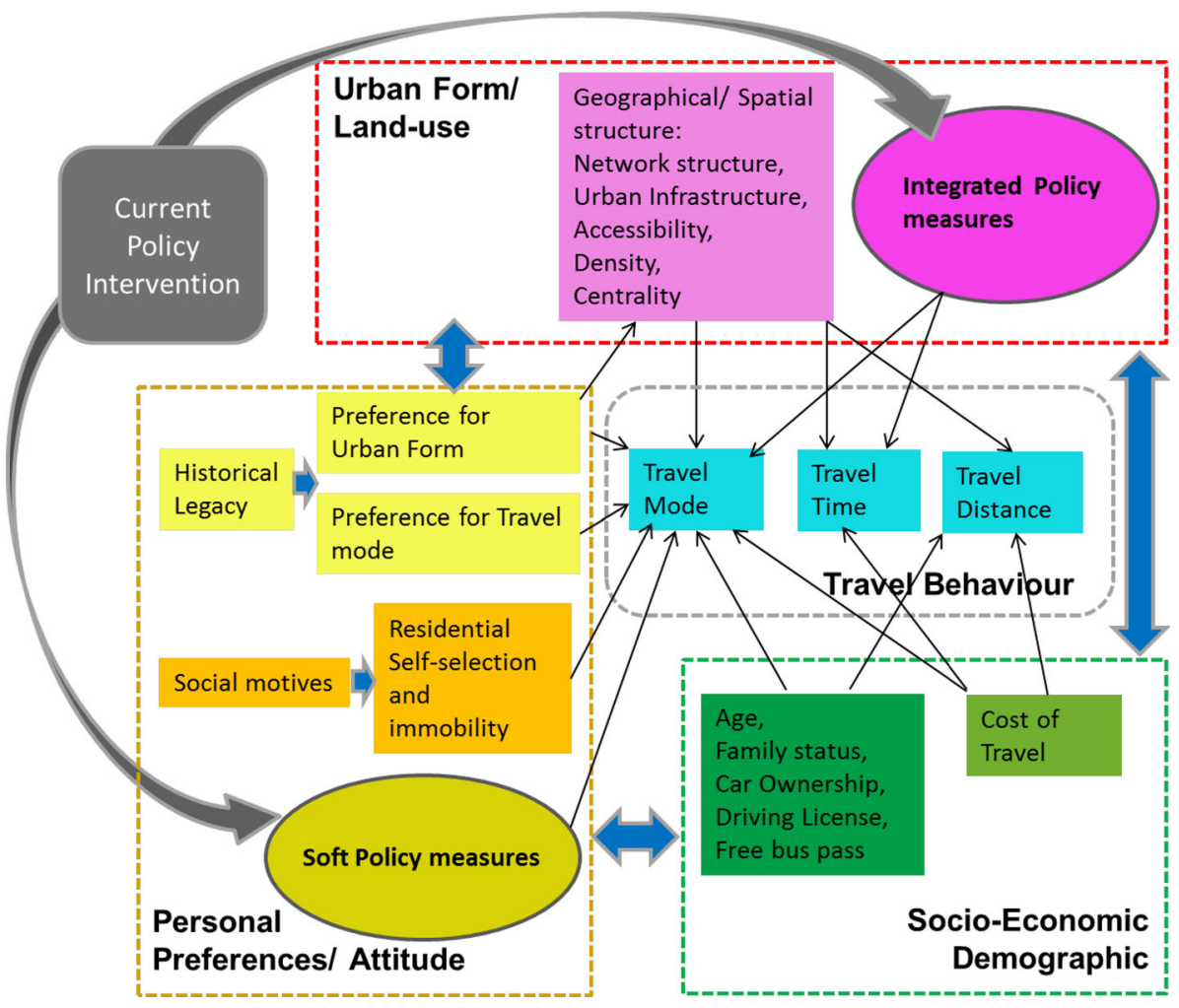

\section{Materials and methods}

The existing literature on the effect of urban form on travel behaviour is dominated by studies that have attempted at establishing the strength of the relationship, thus overemphasizing on the quantitative association as opposed to a qualitative exploration of the interdependencies (Handy 1996). Qualitative studies, although rare in this field, are best suited to explore this dimension as they are interpretive in nature and aim at discovering the concepts and relationships to offer a theoretical explanation for the existing phenomenon (Strauss and Corbin 1998). Since research findings have differed on the basis of contextual setting, a qualitative exploration is warranted as the inherent weakness of this method in terms of generalizability is the strength of this exploration as it shall add the depth to studies engaging in quantitative association for the particular context. This study has thus adopted an inductive approach to develop a theoretical understanding of the social phenomenon involving human decisions to understand the underlying constructs that link urban form and travel behaviour.

Case study area selection

Northern Ireland comprises of about $3 \%$ of the total UK population (NISRA \& ONS) and $38 \%$ of the population of Northern Ireland alone reside within the Belfast
Metropolitan Area (The Planning Service November 2004). However, a contrasting difference is that while $80 \%$ of the UK population now live in urbanized areas (Banister 2007), only $63.6 \%$ of the Northern Ireland population live in urbanized areas (NINIS 2011). The urban spectrum in Northern Ireland is defined in terms of the available infrastructure into four bands (Department for Regional Development 2010), where three bands are urban and the other represents rural. The three case study areas chosen to represent these three bands are; Level 4 represented by Ballynafeigh ward in Belfast, Level 3 represented by Knockmore ward in Lisburn and Level 2 represented by Banbridge West ward in Banbridge. Thus, the whole range of the urban spectrum has been taken into account to look for the association between the urban form and travel behaviour. Since the qualitative studies are context specific in terms of validity, this data shall be representative of Northern Ireland for greater geographical generalizability (Fig. 2).

Also the geographical extent of Northern Ireland is not so vast enabling commute to almost any location from another within reasonable commute distance and time. For this reason, the aim was to select these three study areas along a major arterial route with increasing distance from the Belfast city centre such that each represents an innercity area, a suburb and a commuter town, respectively. While Northern Ireland is perceived as vastly rural with a Belfast-centric approach, the distance to the Belfast city 


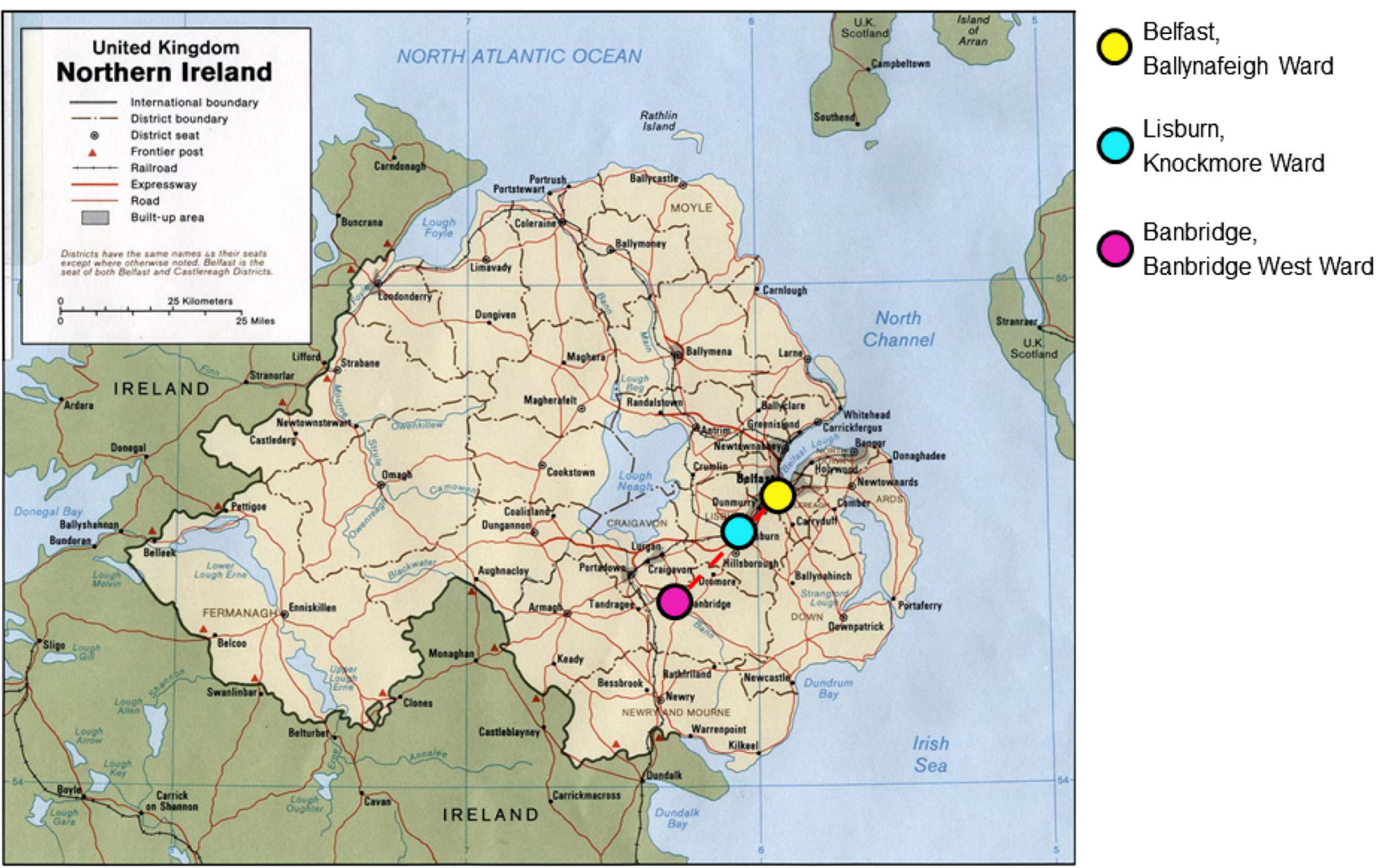

Fig. 2 Map showing location of case study areas in Northern Ireland

centre is a key criteria involving commute traffic for analysing the changes in travel patterns along the urban continuum. Figure 1 shows the location of these three case study areas.

Another consideration taken into account was the concern of researchers that traditional data collection in the field of travel behaviour at the individual level (disaggregate level) strongly reflects more personal and household co-relations leading to bias in explanatory variables (Snellen et al. 2002). To overcome this bias, the case study areas need to be selected in such a fashion that there is weak co-relation between the explanatory variable by selecting neighbourhoods with varying urban form and transportation network combinations. Thus, macro-scale area descriptors at the electoral ward level (density, car ownership, public transport network) were used as indicators to select the case study areas using aggregate level secondary data. Multiple deprivation unit measures were used to look for neighbourhoods in the middle band so that socio-economic conditions do not dominate and flaw the results. Table 1 shows the case study area statistics.

\section{Participants}

The study was conducted between January and May 2013 using focus group discussions and in-depth interviews to explore the travel behaviour of the people in Northern Ireland. A two-prong approach was adopted to investigate the issue from both the user and provider perspective. Thus, focus group discussions were aimed at capturing the user perspective, while the in-depth interviews were aimed at the provider perspective. The focus groups were used to gather the range of issues influencing travel behaviour. On the other hand, the in-depth interviews were used to gain a better understanding of these issues and also selectively target members of the population to fill in the gap or missing information in the data which is of theoretical relevance to the study. Finally, the interviews were used to reach a saturation of concepts such that there were no more new issues emerging from the data.

A total of six focus group discussions were conducted (two from each case study area). The aim was to recruit residents from each of the selected case study areas. The groups were recruited using a list of community organizations, parent teacher associations, local clubs and other social groups. The diversity of the participants in terms of age, ethnicity, occupation, car ownership, gender, socio-economic status and community involvement added to the richness of data. Table 2 shows the focus group participant's profile.

A total of seventeen in-depth interviews were conducted comprising of members of staff in the local councils, government organizations, active community members and 
Table 1 Case study area statistics

\begin{tabular}{|c|c|c|c|c|c|c|c|}
\hline $\begin{array}{l}\text { Sl. } \\
\text { No. }\end{array}$ & Case study area & Population & $\begin{array}{l}\text { Density } \\
\text { (pa/ha) }\end{array}$ & $\begin{array}{l}\text { Car } \\
\text { ownership } \\
(\%)\end{array}$ & $\begin{array}{l}\text { Multiple } \\
\text { deprivation unit }\end{array}$ & Linkage & Land use \\
\hline 1 & $\begin{array}{l}\text { Ballynafeigh ward, } \\
\text { Belfast }\end{array}$ & 5,928 & 88.48 & 37.18 & 251 & $\begin{array}{l}\text { Rail, Motorway, } \\
\text { Port, Airport }\end{array}$ & $\begin{array}{l}\text { Shopping/commercial area, open } \\
\text { space and Housing }\end{array}$ \\
\hline 2 & $\begin{array}{l}\text { Banbridge west } \\
\text { ward, Banbridge }\end{array}$ & 3,006 & 22.88 & 86.57 & 289 & Motorway & $\begin{array}{l}\text { Existing employment/industry, } \\
\text { open space, housing }\end{array}$ \\
\hline 3 & $\begin{array}{l}\text { Knockmore ward, } \\
\text { Lisburn }\end{array}$ & 4,298 & 9.96 & 82.96 & 285 & Rail, Motorway & $\begin{array}{l}\text { Existing employment/industry, } \\
\text { open space, housing }\end{array}$ \\
\hline
\end{tabular}

local experts. The interviewees in general represented the more educated professionals with one female and sixteen male participants; however, the focus group participants were more diverse in terms of socio-demographical composition, thus avoiding a bias in the data. Table 3 shows the in-depth interview participant's profile (Tables 4,5 ).

Procedure and schedule

The focus group discussions were conducted in the group's usual meeting place except in one situation in Knockmore where a pre-arranged venue was arranged. The discussions lasted typically between 35 and $50 \mathrm{~min}$ and were audio recorded with the participants' consent. The in-depth interviews were all conducted in the individual's workplace and lasted between $35 \mathrm{~min}$ to $1 \mathrm{~h}$ and $15 \mathrm{~min}$, which were audio recorded as well with the interviewee's consent.

Both the focus group discussions and in-depth interviews were semi-structured with the nature of questions pertinent to the method of enquiry starting with a broad general question. The length at which each issue was discussed reflected the importance of the issue to the participant. Thus, a variety of motives and opinions were explored in terms of their general perception of travel behaviour covering a range of topics relating to perceptions and preferences of urban form and travel behaviour which further highlights the relevant influencing factors in the Northern Ireland context.

For the focus groups, participants were identified through community groups and contact was established, usually by phone call, with the leader of each group who was the contact point for consent and arrangement of the focus group discussion. The interviewee's were primarily contacted by email, and the rest were recruited using a snowball technique. At the end of each interview, the expert was asked to recommend other professionals who could further contribute to this study.

\section{Grounded theory analysis}

Grounded theory is an inductive approach through which theory is generated from the data which is systematically collected and analysed rather than testing a preconceived idea or hypothesis (Strauss and Corbin 1998; Dey 2004; Glaser 1992). The inception of this methodology in sociology was to bridge the gap between the two parallel universes of 'theory' and 'empirical research' by connecting theory to evidence through the process of engaging with the data rather than using a deductive approach (Dey 2004). Thus, the aim of grounded theory is to build a theory rather than test a theory by identifying concepts and developing them to form the building blocks of the theory (Strauss and Corbin 1998). Although it is clearly a qualitative method for data analysis, the strength of this method lies in its endeavour to integrate the rigor and logic of quantitative methods with the sensitivity of qualitative approaches (Walker and Myrick 2006). The appropriateness of this method for this study thus lies in the goal to generate a theory systematically from the data that is distinctive of this qualitative method (Walker and Myrick 2006), which can identify the underlying constructs that links urban form with travel behaviour for more holistic and robust conclusions.

The constant comparative method of grounded theory analysis has been adopted for this study following the guidelines proposed by Strauss and Corbin (1998), which divides the data analysis process into three main phases of coding; open coding, axial coding and selective coding (Strauss and Corbin 1998; Dey 2004; Dey 2004; Gardner and Abraham 2007). Prior to this, the data are transcribed verbatim to facilitate the analysis which follows a series of systematic coding thus lending meaning to the data. Thus, initially the data are fragmented and examined, and conceptual labels are assigned after conceptualizing, comparing and categorizing the data (Strauss and Corbin 1998; Dey 2004; Gardner and Abraham 2007). However, the aim of this study was to look for interrelationship patterns for which key point coding was used which involves selection of concepts and patterns instead of a micro-analysis approach, which fragments the data into individual words thus losing the link (Glaser 1992; Allan 2003) which is the key objective of this study. Although there is a rift between the two founders of grounded theory on this issue of over conceptualization and over burden of data, Strauss and 
Table 2 Focus group participant profile

\begin{tabular}{|c|c|c|c|c|c|c|c|c|}
\hline $\begin{array}{l}\text { S1. } \\
\text { no. }\end{array}$ & & $\begin{array}{l}\text { FG } 1 \\
\text { Youth centre } \\
\text { (Ballynafeigh) }\end{array}$ & $\begin{array}{l}\text { FG } 2 \\
\text { Community centre } \\
\text { (Ballynafeigh) }\end{array}$ & $\begin{array}{l}\text { FG } 3 \\
\text { Football club } \\
\text { (Knockmore) }\end{array}$ & $\begin{array}{l}\text { FG } 4 \\
\text { Local residents } \\
\text { (Knockmore) }\end{array}$ & $\begin{array}{l}\text { FG } 5 \\
\text { School PTA } \\
\text { (Banbridge) }\end{array}$ & $\begin{array}{l}\text { FG } 6 \\
\text { Boxing club } \\
\text { (Banbridge) }\end{array}$ & Total \\
\hline 1 & $\begin{array}{l}\text { Number of } \\
\text { participants }\end{array}$ & 5 & 6 & 5 & 5 & 8 & 7 & 36 \\
\hline \multirow[t]{3}{*}{2} & Gender & & & & & & & \\
\hline & Male & 2 & 2 & 5 & 2 & 2 & 6 & 19 \\
\hline & Female & 3 & 4 & 0 & 3 & 6 & 1 & 17 \\
\hline 3 & $\begin{array}{l}\text { Full driving } \\
\text { license }\end{array}$ & 1 & 3 & 4 & 4 & 5 & 6 & 23 \\
\hline 4 & Car ownership & 1 & 1 & 4 & 4 & 5 & 6 & 21 \\
\hline \multirow[t]{3}{*}{5} & $\begin{array}{l}\text { Age of } \\
\text { participants } \\
\text { (years) }\end{array}$ & & & & & & & \\
\hline & Range & $18-32$ & $26-52$ & $19-49$ & $25-36$ & $18-55$ & $18-68$ & $18-68$ \\
\hline & Mean age & 21.2 . & 38.33 & 38.4 & 32.8 & 34.75 & 42.14 & \\
\hline
\end{tabular}

Table 3 Interview participant's profile

\begin{tabular}{llll}
\hline $\begin{array}{l}\text { S1. } \\
\text { no. }\end{array}$ & Type of organization & $\begin{array}{l}\text { No. of } \\
\text { interviewees }\end{array}$ & $\begin{array}{l}\text { Study area } \\
\text { reference }\end{array}$ \\
\hline 1 & $\begin{array}{c}\text { Department for Regional } \\
\text { Development NI }\end{array}$ & 4 & Belfast \\
& Department of the & 1 & Banbridge \\
2 & Environment NI & 1 & Belfast \\
& & 1 & Lisburn \\
& & 1 & Banbridge \\
3 & Local politician & 1 & Banbridge \\
4 & Community organization & 1 & Banbridge \\
5 & Builder & 2 & Lisburn \\
6 & City council & 1 & Lisburn \\
& & 1 & Banbridge \\
7 & Translink & 17 & Belfast \\
& Total & & \\
\hline
\end{tabular}

Corbin have stated the application of this micro-coding process to the relevant data only and not the whole transcript, which could effectively end up with more data to analyse (Strauss and Corbin 1998). Thus, while this process forms the building blocks of the whole analysis, researchers' need to make a choice to adopt either the key point coding approach (Glaser 1992) or micro-coding approach (Strauss and Corbin 1998) whichever best suits their research aims. This is followed by the axial coding which then looks at the relationship between these conceptual labels and then links them with overarching categories. Finally, the selective coding involves the selection of a core category that links the overarching categories to generate an understanding of the interrelationship between the categories and also filling in categories that need further development and refinement. Thus, the whole process is data driven as the categories reflect the issues that are of importance and were discussed in the in-depth interviews and focus group discussions. However, due to the large number and wide range of participants, we also find patterns of perception and reasoning associated with their travel decisions. This allows us to identify the contextually relevant indicators associated with urban form and travel behaviour which can be subsequently tested using a larger population and quantitative methods.

The interviews and focus group discussions were transcribed verbatim and were read and re-read before coding and assigning labels. For example, when asked to comment on general travel patterns, a focus group participant in Belfast commented.

For me it would be like most of the places I am going are nearby and I am able to walk there, so it's just convenient to walk. You wouldn't even need a bus to most of the places I am going, however, if it is a further distance then I would use a bus, but more commonly I would walk'. (Male, 18 years, Belfast)

This statement was initially given several provisional conceptual codes in the open coding process: proximity to activities and mode choice, residential location and mode choice, city living and active travel and access to public transport and absence of car. Further open coding refined these concepts and compared them with other codes to develop an overarching category through axial coding which was the 'spatial context and travel mode choice'. After identifying the overarching categories, the final central core category was selected in the selective coding process which explained how these categories were interrelated. 
Table 4 Car ownership profile of participants

\begin{tabular}{|c|c|c|c|c|c|c|c|c|c|c|c|c|}
\hline \multirow[t]{3}{*}{ Age } & \multicolumn{4}{|c|}{ Belfast (city) } & \multicolumn{4}{|c|}{ Lisburn (suburb) } & \multicolumn{4}{|c|}{ Banbridge (commuter town) } \\
\hline & \multicolumn{2}{|c|}{ Male } & \multicolumn{2}{|c|}{ Female } & \multicolumn{2}{|c|}{ Male } & \multicolumn{2}{|c|}{ Female } & \multicolumn{2}{|c|}{ Male } & \multicolumn{2}{|c|}{ Female } \\
\hline & Yes & No & Yes & No & Yes & No & Yes & No & Yes & No & Yes & No \\
\hline $17-25$ & & 2 & 1 & 1 & 2 & & & & 1 & 3 & & \\
\hline $26-35$ & 2 & 1 & 1 & 2 & & & 2 & 1 & & & 1 & 1 \\
\hline $36-45$ & 3 & & & & 3 & 1 & 1 & & 1 & & 2 & \\
\hline $46-55$ & 2 & 1 & & 2 & 4 & & & & 6 & & 3 & \\
\hline $56-65$ & 1 & & & & & & & & & & & \\
\hline$>65$ & & & & & & & & & 2 & & & \\
\hline Total & 8 & 4 & 2 & 5 & 9 & 1 & 3 & 1 & 10 & 3 & 6 & 1 \\
\hline
\end{tabular}

Table 5 Full driving license holder profile of participants

\begin{tabular}{|c|c|c|c|c|c|c|c|c|c|c|c|c|}
\hline \multirow[t]{3}{*}{ Age } & \multicolumn{4}{|c|}{ Belfast (City) } & \multicolumn{4}{|c|}{ Lisburn (Suburb) } & \multicolumn{4}{|c|}{ Banbridge (Commuter town) } \\
\hline & \multicolumn{2}{|l|}{ Male } & \multicolumn{2}{|c|}{ Female } & \multicolumn{2}{|c|}{ Male } & \multicolumn{2}{|c|}{ Female } & \multicolumn{2}{|c|}{ Male } & \multicolumn{2}{|c|}{ Female } \\
\hline & Yes & No & Yes & No & Yes & No & Yes & No & Yes & No & Yes & No \\
\hline $17-25$ & & 2 & 1 & 1 & 2 & & & & 1 & 3 & & \\
\hline $26-35$ & 2 & 1 & 2 & 1 & & & 2 & 1 & & & 1 & 1 \\
\hline $36-45$ & 3 & & & & 3 & 1 & 1 & & 1 & & 2 & \\
\hline $46-55$ & 2 & 1 & 1 & 1 & 4 & & & & 6 & & 3 & \\
\hline $56-65$ & 1 & & & & & & & & & & & \\
\hline$>65$ & & & & & & & & & 2 & & & \\
\hline Total & 8 & 4 & 4 & 3 & 9 & 1 & 3 & 1 & 10 & 3 & 6 & 1 \\
\hline
\end{tabular}

To our knowledge, this is the first attempt to use a grounded theory analysis to understand the role and mechanism of urban form, socio-economic factors, demographics, attitudes and preferences in influencing travel behaviour. However, earlier studies aimed at understanding factors associated with psychological experiences have implemented this method successfully in the field of travel behaviour (Gardner and Abraham 2007).

\section{Results and discussion}

This section discusses the seven major overarching categories extracted from the transcripts. Four of these categories explain the role of urban form in influencing car dependency: the spatial configuration, residential location selection to suit social constructs constraining travel mode choice, historical past influencing residential and travel choices and the cost of travel variations in relation to the urban form at residential location influencing mode choice. Thus, the urban form at the residential location dominates travel choices in terms of mode selection. The fifth category reflects the socio-demographics influencing travel mode choice; however, urban form remains the main facilitator in providing these choices. The two other overarching categories are linked to the policy measures targeted at these two major issues - the residential location and car dependency, to offer an insight into the barriers and success of policy implementation to influence residential location and car dependency. Table 6 shows the interrelationship patterns and the following sections discuss these overarching categories in more detail.

The spatial context and travel mode choice

The geography of Northern Ireland plays a unique role in shaping the transport network and hence travel patterns, particularly in terms of the modality. Belfast City in particular is bounded by the hills on two sides and the Belfast Lough on the third side. Thus, a southern expansion of the city towards Lisburn was a natural geographical phenomenon, and within the city, the public transport network is of a radial structure as a result of the topographical 'bowl' effect. However, these radial routes mean that there are excellent public transport connections to go to the city centre from any point on the radial routes, however, to go 
Table 6 Overarching categories showing the underlying constructs linking factors influencing travel behaviour

\begin{tabular}{|c|c|c|c|c|c|}
\hline SL.NO. & CATEGORY & & \multicolumn{2}{|c|}{ INTER-RELATIONSHIP PATTERN } & TRAVEL ASPECT \\
\hline \multirow{7}{*}{1} & \multirow{7}{*}{$\begin{array}{l}\text { SPATIAL/GEOGRAPHICAL } \\
\text { CONTEXT }\end{array}$} & \multirow{7}{*}{ 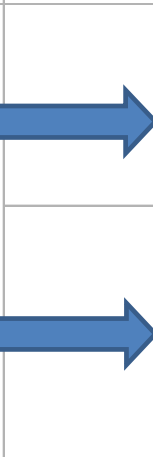 } & \multirow{3}{*}{ MACRO LEVEL } & $\begin{array}{l}\text { Geographical extent of } \mathrm{NI} \text { not very vast enabling daily commute to most } \\
\text { parts within reasonable time. }\end{array}$ & \multirow{7}{*}{$\begin{array}{l}\text { IMPACT ON TRAVEL } \\
\text { MODE (CAR } \\
\text { DEPENDENCY) }\end{array}$} \\
\hline & & & & $\begin{array}{l}\text { Over generous road share per capita (mostly rural) complimenting the } \\
\text { prevalent anti-urban sentiment. }\end{array}$ & \\
\hline & & & & $\begin{array}{l}\text { Growth of Commuter towns along motorway with urban amenities and } \\
\text { facilities but rural lifestyle becoming more popular. }\end{array}$ & \\
\hline & & & \multirow{4}{*}{ MICRO LEVEL } & $\begin{array}{l}\text { Spatial setting of Belfast giving rise to radial Public Transport network - } \\
\text { excellent connectivity towards city centre but longer journey times to other } \\
\text { parts. }\end{array}$ & \\
\hline & & & & $\begin{array}{l}\text { Public transport service and facility challenged towards outer city limits and } \\
\text { perceived as non-existent in outer areas. }\end{array}$ & \\
\hline & & & & $\begin{array}{l}\text { Public Transport reliance leading to social exclusion beyond city limits and } \\
\text { car related to independency. }\end{array}$ & \\
\hline & & & & Lack of consistent urban infrastructure (cycling lanes) for alternative mode. & \\
\hline \multirow{6}{*}{2} & \multirow{6}{*}{$\begin{array}{l}\text { HISTORICAL LEGACY } \\
\text { (Impact of 'Troubles' and } \\
\text { Political decisions) }\end{array}$} & \multirow{6}{*}{$\begin{array}{l}\text { IMPACT ON } \\
\text { ATTITUDE } \\
\text { AND } \\
\text { PERCEPTION } \\
\text { TOWARDS }\end{array}$} & \multirow{3}{*}{ URBAN FORM } & Outmigration and selection of Urban form associated with safety and kinship. & \multirow{6}{*}{$\begin{array}{l}\text { IMPACT ON TRAVEL } \\
\text { MODE (CAR } \\
\text { DEPENDENCY) }\end{array}$} \\
\hline & & & & Loss of critical mass in the city to support public transport infrastructure & \\
\hline & & & & $\begin{array}{l}\text { In Belfast, the 'right-to-buy' scheme caused outward displacement from the } \\
\text { city core to outlying areas - thus loss of local community due to private } \\
\text { housing market. }\end{array}$ & \\
\hline & & & \multirow{3}{*}{$\begin{array}{l}\text { TRAVEL } \\
\text { BEHAVIOUR }\end{array}$} & $\begin{array}{l}\text { Uncertainty of public transport and independence and safety of private car } \\
\text { during the troubles perpetuated itself through the generations. }\end{array}$ & \\
\hline & & & & $\begin{array}{l}\text { Para-transit system created during the troubles still serving the local } \\
\text { community and preferred over PT. }\end{array}$ & \\
\hline & & & & $\begin{array}{l}\text { Political slogans such as -'if you take the bus you are a loser' - creates a } \\
\text { negative image of PT and train has a better imageability in the wealthier } \\
\text { parts of Belfast than bus. }\end{array}$ & \\
\hline \multirow{8}{*}{3} & \multirow{8}{*}{ PERSONAL PREFERENCES } & & \multirow{4}{*}{$\begin{array}{c}\text { SOCIAL } \\
\text { MOTIVES AND } \\
\text { RESIDENTIAL } \\
\text { IMMOBILITY }\end{array}$} & $\begin{array}{l}\text { Residential location is more important than travel options due to strong } \\
\text { preferences. }\end{array}$ & \multirow{8}{*}{$\begin{array}{l}\text { IMPACT ON TRAVEL } \\
\text { MODE AND TRAVEL } \\
\text { DISTANCE }\end{array}$} \\
\hline & & & & $\begin{array}{l}\text { Familiarity with area, local connections very strong determinants of } \\
\text { residential location selection. }\end{array}$ & \\
\hline & & & & $\begin{array}{l}\text { Residential location selection based on living close to family for child care } \\
\text { help and family support. }\end{array}$ & \\
\hline & & & & $\begin{array}{l}\text { Absence of rental culture in } \mathrm{NI} \text { coupled with uncertainly of early career job } \\
\text { leading to buying house near family. }\end{array}$ & \\
\hline & & & \multirow{4}{*}{$\begin{array}{l}\text { LIFE-CYCLE } \\
\text { PROCESS }\end{array}$} & Younger professionals and students prefer city living. & \\
\hline & & & & $\begin{array}{l}\text { Families with children tend to live outside the city near family for support } \\
\text { and for more space. }\end{array}$ & \\
\hline & & & & $\begin{array}{l}\text { Household structure (absence of children) determines travel option priority } \\
\text { and city living. }\end{array}$ & \\
\hline & & & & $\begin{array}{l}\text { Relocation in life cycle linked to downsizing but still guided by social } \\
\text { connections and familiarity. }\end{array}$ & \\
\hline \multirow{5}{*}{4} & \multirow{5}{*}{$\begin{array}{l}\text { ECONOMICS OF } \\
\text { TRAVEL }\end{array}$} & \multirow{5}{*}{$\begin{array}{l}\text { COST OF } \\
\text { TRAVEL very } \\
\text { important but } \\
\text { dependant on } \\
\text { RELATIVE } \\
\text { URBAN } \\
\text { LOCATION }\end{array}$} & \multirow{5}{*}{$\begin{array}{l}\text { NNER CITY } \\
\text { AREA }\end{array}$} & $\begin{array}{l}\text { Car is perceived as an added cost since most destinations can be reached } \\
\text { on foot or bus. }\end{array}$ & \multirow{5}{*}{$\begin{array}{l}\text { JMPACT ON TRAVEL } \\
\text { MODE CHOICE }\end{array}$} \\
\hline & & & & $\begin{array}{l}\text { People tend to choose to not having a car despite having full driving license } \\
\text { to save money. }\end{array}$ & \\
\hline & & & & $\begin{array}{l}\text { Public Transport is considered more expensive to use when one is already } \\
\text { maintaining a car. }\end{array}$ & \\
\hline & & & & $\begin{array}{l}\text { Cost of Public Transport is equated against cost of fuel only and car travel is } \\
\text { often found cheaper. }\end{array}$ & \\
\hline & & & & $\begin{array}{l}\text { Driving license and car are simply a necessity so that job options are not } \\
\text { effected. }\end{array}$ & \\
\hline \multirow{6}{*}{5} & \multirow{6}{*}{$\begin{array}{l}\text { SOCIO- } \\
\text { DEMOGRAPHICS }\end{array}$} & \multirow{6}{*}{$\begin{array}{c}\text { CAR } \\
\text { OWNERSHIP, } \\
\text { DRIVING } \\
\text { LICENSE, AGE, } \\
\text { FAMILY } \\
\text { STATUS,FREE } \\
\text { BUS PASS - } \\
\text { Major } \\
\text { determinants } \\
\text { of Public } \\
\text { Transport }\end{array}$} & \multirow{6}{*}{$\begin{array}{l}\text { OUTER URBAN } \\
\text { AREAS }\end{array}$} & Modal shift from public transport to car due to young children. & \multirow{6}{*}{$\begin{array}{l}\text { YMPACT ON TRAVEL } \\
\text { MODE (PUBIC } \\
\text { TRANSPORT } \\
\text { PATRONAGE) }\end{array}$} \\
\hline & & & & Public transport unsuitable for families who do trip chaining. & \\
\hline & & & & $\begin{array}{l}\text { Unavailability of car or driving license leading to public transport usage in } \\
\text { some cases - thus PT patronage not a choice. }\end{array}$ & \\
\hline & & & & $\begin{array}{l}\text { Public Transport is mainly used by students who don't have license and } \\
\text { cars and the elderly who don't want to keep a car. }\end{array}$ & \\
\hline & & & & Free bus pass holders switching to public transport due to free travel option. & \\
\hline & & & & Retired people who don't have time constraint use public transport. & \\
\hline
\end{tabular}


Table 6 continued

\begin{tabular}{|c|c|c|c|c|}
\hline SL.NO. & CATEGORY & & INTER-RELATIONSHIP PATTERN & TRAVEL ASPECT \\
\hline \multirow{8}{*}{6} & \multirow{8}{*}{$\begin{array}{l}\text { IMPLEMENTTION AND } \\
\text { ACCEPTANCE OF } \\
\text { INTEGRATED POLICY } \\
\text { MEASURES }\end{array}$} & \multirow{4}{*}{$\begin{array}{c}\text { INNER CITY } \\
\text { CORE: Park \& } \\
\text { Ride Schemes }\end{array}$} & $\begin{array}{l}\text { Policy aiming at improving accessibility using modal split and restraint } \\
\text { measures towards city core. }\end{array}$ & \multirow{8}{*}{$\begin{array}{l}\text { IMPACT ON MODAL } \\
\text { SPLIT }\end{array}$} \\
\hline & & & $\begin{array}{l}\text { Huge uproar by road users due to introduction of dedicated bus lanes in } \\
\text { city centre. }\end{array}$ & \\
\hline & & & $\begin{array}{l}\text { Although authorities claim the effectiveness of these schemes, general } \\
\text { public sceptic. }\end{array}$ & \\
\hline & & & Free car parking spaces in inner city a major barrier to these schemes. & \\
\hline & & \multirow{4}{*}{$\begin{array}{l}\text { OTHER URBAN } \\
\text { AREAS: } \\
\text { Brownfield } \\
\text { Regeneration } \\
\text { Initiatives }\end{array}$} & $\begin{array}{l}\text { Policy aiming at improving the connectivity between new housing growth and } \\
\text { transportation }\end{array}$ & \\
\hline & & & $\begin{array}{l}\text { Also initiatives to link with railway in the form of transit oriented development } \\
\text { but schemes still in infancy. }\end{array}$ & \\
\hline & & & Economic downturn another barrier to such integrated efforts. & \\
\hline & & & $\begin{array}{l}\text { Lack of legislative power due to current fragmented departments to enforce } \\
\text { integrated transport measures with planning application. }\end{array}$ & \\
\hline \multirow{6}{*}{7} & \multirow{6}{*}{$\begin{array}{l}\text { TRENDS WITHIN TRENDS - } \\
\text { The shifting Scenario }\end{array}$} & \multirow{3}{*}{$\begin{array}{l}\text { SOFT POLICY } \\
\text { MEASURES }\end{array}$} & $\begin{array}{l}\text { General awareness on environmental issues from childhood leading to } \\
\text { change in behaviour. }\end{array}$ & \multirow{6}{*}{$\begin{array}{l}\text { NMPACT ON MODAL } \\
\text { SPLIT }\end{array}$} \\
\hline & & & Slogans to influence train ridership led to surge in passenger numbers. & \\
\hline & & & $\begin{array}{l}\text { Local residents did not mention any soft policy reflecting their importance as } \\
\text { compared to hard policy measures. }\end{array}$ & \\
\hline & & \multirow{3}{*}{$\begin{array}{l}\text { TAILOR-MADE } \\
\text { TRAVEL } \\
\text { OPTIONS }\end{array}$} & $\begin{array}{l}\text { Tailor made travel options for the youth led to increase in public transport } \\
\text { patronage in students. }\end{array}$ & \\
\hline & & & Use of public transport for longer commute noted in the new generation. & \\
\hline & & & Gradual shift in perception noted in the new generation. & \\
\hline
\end{tabular}

to any other part of the city one has to go to the centre first and then go out along that route. This means unnecessary longer journeys and extended travel times which diminishes the effectiveness of public transport.

'....it is a bit awkward to get to some parts of the city to other parts of the city because the way the bus service runs..... it's like the spokes of a wheel. If you want to move down the spoke to the city - it is easy, but of you want to get to a place on another spoke.......' (Male, 49 years, Ballynafeigh ward, Belfast)

This situation gets more acute as we move further down the urban spectrum and outside the main city limits where people's perception of travel mode completely changes along with their perception of urban form.

'Private car is the main transport option..............

Northern Ireland is very rural in nature, two miles and you are in the countryside...... so if you are out of Belfast or maximum Lisburn, you are not left with any other option'. (Male, 46 years, Banbridge)

And this rural nature of Northern Ireland is supported by a generous road infrastructure which almost directly promotes the use of car. So while this spread-out rural nature of Northern Ireland exacerbates the car dependency, there seems really no other option as public transport cannot cater to all the different destinations that one may wish to go from a small town. Thus, as one moves out of Belfast, the rest of Northern Ireland is mostly perceived as rural. This is compounded by the aspiration and preference of the locals for rural countryside living which is somewhat shaped by traditional values which perceives the car as the only mode of transport.

'The way you are brought up.... it obviously has an effect on the way you live...... there was no other option than to use the car and I think that has manifested itself in the later years, it breeds car dependency into ourselves as well...' (Female, 35 years, Lisburn)

Thus, car ownership has a strong cultural association and is representative of freedom and independence. Also the tendency of outmigration from the main city created the commuter towns which are situated outside the cities but are not so rural and isolated in nature. This may be perceived as a compromise to achieve mass location without hurting the anti-urban sentiment and is gaining popularity as smaller towns have almost doubled in population due to inwardmigration.

'Banbridge is a thriving town in one sense but basically it is a dormitory town for Belfast'. (Male, 67 years, Banbridge)

'Because it is sitting on the A1 it is easier to travel....30 min takes you to Craigavon, 15 min takes 
you to Newry, 40 min takes you to Belfast. So people could actually live here and commute'. (Male, 53 years, Banbridge)

The reason for choosing to live in these commuter towns is the urban infrastructure, linkages and amenities it has to offer besides fulfilling the desire for suburban or rural living. However, encouraging patterns have been observed like car sharing, which is gaining popularity in these towns although mainly among residents who were more educated and working in offices. One reason for car sharing is their common destination and similar job profile but again there is a possibility that issues relating to environmental awareness have been instilled into them through travel plans and other soft policy measures at their workplace.

But on a broader perspective relating to the spatial context of Northern Ireland, the geographical size is the main reason for the sprawl and car travel as most destinations would still be within commute range.

'....because Northern Ireland is a small country, an hour or so will take you everywhere....' (Male, 46 years, Banbridge)

Thus, there is a strong connection between the spatial context of Northern Ireland and travel patterns although there are quite a few mediating factors like perception, preferences, past experience and other catalysts. We shall discuss these in more detail in the following sections.

Impact of historical legacy on attitudes and perceptions

The legacy of 'the troubles' arising from ethno-national conflicts in Northern Ireland has had a deep impact on the city's physical and social structure leading to social and residential mobility inequalities. An outmigration was the immediate consequence which led to the loss of inner-city population needed for the critical mass to support public transport infrastructure.

'.....it's creating the critical mass to be able to run an efficient and all day long PT service. So while you had the other cities in the 60's and 70's losing their population for different economic reasons, we were losing ours for economic and social reasons...'. (Male, 41 years, Belfast)

The disrupted travel patterns and unreliable public transport consequently resulted in the reliance on private car. This feeling of fear and insecurity which has been translated through the generations still guide travel choices in daily life. This also resulted in social mobility inequalities as people would remain contained in certain areas to which they associate their safety and kinship, and these observations were not only in Belfast but also in other parts of the country. When asked for the reason for living in a particular area, the response of a participant immediately echoed these ethno-national conflicts.

'....Honestly?... Cause this is a Loyalist area'. (Male, 49 years, Knockmore, Lisburn)

People have also had the same reason to move out of areas they were previously living in search of more neutral areas and vice versa due to personal and social reasons. While these issues dominate the decision for residential selection, all other issues like travel choices become secondary. A polarization is created resulting in the fragmentation of the urban fabric which has impacts on both infrastructure provision and travel choices, and travel patterns are altered to suit the primary concerns.

Again speaking of historical legacy, it is not only issues related to 'the troubles' that have left an impact on the society, but also political decisions and policy that have caused outward displacement from the city core. One such interesting issue was discovered in the Belfast context where the impact of one of the policies of the Thatcher government - the 'right to buy' scheme-has left a lasting impression on the local community. While a participant praised it as the support to get on the housing ladder, there were still others of a different view.

'...that is how some people get on to the housing market, if that never happened, you know, they would never be able to progress from there. No... its my family.....its reality for us!...' (Female, 29 years, Ballynafeigh, Belfast)

'...But Margaret Thatcher, ...I don't deny that she enabled individual's own progress, but it had an impact on the community!..' (Male, 49 years, Ballynafeigh, Belfast)

Thus, a forced displacement of population out of the city centre took place contrary to the objective of the compact city and replaced by a transient population who did not have much bearing with the local community. In terms of transport, this may be viewed as introducing a car dependency among the residents who were public transport users due to the lack of equal transport infrastructure in the new displaced residential locations.

Also often going unnoticed are some strong political statements that strongly influence people's perception of transport modes. One such interesting comment was made by an interviewee in relation to buses in the city.

'.......Like if they have the Maggi Thatcher mentality..... that if you take the bus you are a loser..... They will never take it if they have it in their heads'. (Male, 34 years, Belfast) 
Thus, perceptions have a very strong influence on travel modes, and historical legacy leaves behind impressions which are translated through the generations.

\section{Social motives and residential immobility}

Longer travel distances, be it for commute or any other purpose, is a common observation in many parts of the globe today (Schwanen et al. 2001; Susilo and Maat 2007), and the reason for this is the distance between the residential location and other activity locations. While the values attached to family connections, social motives and familiarity with the area are given primacy by almost all the participants and interviewees from across the case study areas; these values were also guided to some extent by factors related to urban form characteristics in some ways.

'...It is about personal preference.... that is my community, I am a rural person. The family is there around me... I'm connected to the church... Too strong connections'. (Male, 53 years, Banbridge)

Living close to the family is an important reason particularly for families with young children who depend on help from the family for childcare support. While young single professionals find city life attractive, for families with young children there is an economical aspect that needs to be considered as childcare costs still far exceed the longer commute cost in most households. The anti-urban sentiment is thus strengthened by the lack of family support, more residential space and cheaper lifestyle factors.

'...And we get family support living near the family. My sister had exactly that problem. They choose to live in the city and their families are hundred miles away. So they are just there.... and my sister has a $\mathrm{PhD}$.....and she is smart enough and all.... But she had to give up work after the 2 children cause they simply can't afford..... So that's from a city living and not living beside your family... (Female, 35 years, Lisburn)

Participants have also commented on the absence of the 'rent culture' in Northern Ireland. Buying a property in the early stages of life is not dependent on work location as there is uncertainty associated with having that job for a long term. Thus, the tendency is to buy a house near one's family or a familiar place where one grew up. This results in a fixed residential location, and the commute distance varies with variations in job location.

Another bracket of respondents comprised of nonnatives who are a consequence of modern day globalization trends. They present slightly different residential choices, mainly work related although the neighbourhood profile, accessibility and safety concerns are linked to those choices. As they have no long-term bearing with the area, their choices are more directly guided by urban form characteristics and travel choices.

'....It is my husband's job.....he found job in Lisburn,....almost 6 years now in this job'. (Female, 34 years, Knockmore, Lisburn)

'....Lisburn is pretty centrally located for all the places I might have to go to.....' (Male, 37 years, Lisburn)

However, despite all these factors, the residential location takes precedence above all factors for almost all the respondents and they would rather alter their travel patterns as opposed to changing their residential location. There were few exceptions where the absence of children, absence of car or family situation was the reason for residential flexibility and travel issues were given importance by the individual.

Economics of travel patterns in relation to the urban context

Every individual associates a cost to travel, be it the direct cost of travel associated with the mode of travel, travel time calculated in terms of cost, or the cost of road tax, fuel and insurance associated with the mode of travel. This is in line with the economic utility theory which contends that humans make trade-off between travel choices based on available time and money to maximize the utility gain (van de Kaa 2010). In all the three case study areas, it was observed that public transport ridership and the use of car was largely influenced by the cost involved in making the journey using either mode. Thus, the utility perception varied between the inner-city residents of Belfast and the suburbs and further afar towns like Banbridge. While in Ballynafeigh ward, in Belfast, participants have expressed the car as an added cost and not a necessity, outside Belfast using public transport is more expensive as one is already paying to maintain a car, so it is the cost of fuel equated against the cost of tickets which often works out much more expensive, hence the utility of car. Also the perception of the cost was found to be dependent on the relative urban location. For journeys originating outside Belfast, the cost of car worked out cheaper. Thus, the urban form at the residential location seems more influential in determining the mode of travel.

'....Public transport is more expensive than petrol for my car for a week, so that's why I don't do it..... It is over $£ 7$ a ticket from my house to here (Belfast) a day. So it wouldn't pay me to do that....' (Female, 29 years, Ballynafeigh, Belfast) 
The cost of travel thus has a direct role in influencing the travel choices one makes. Although habits, preferences, urban form characteristics are considered influencing factors, affordability poses a major constraint to mode choice.

'...The only thing that will change behaviour apart from hypnotizing people will be money......It's all about the cost of it.' (Male, 53 years, Banbridge)

So while very few people give thought to travel patterns, there are others who are restrained by finances and are obliged to plan their travel schedule to minimize travel costs. So, in a way, the utility maximization theory definitely plays an important role in our travel decisions just as it is no pariah to all other important decisions we take in our daily lives.

Demographical segmentation and driving license determining public transport patronage

Another interesting observation from the focus group discussions and in-depth interviews from all the case study areas alike revealed the variations in travel mode choices among users in terms of human demography. The availability of driving license, car ownership, age, family status and free bus pass are the five major determinants of public transport ridership across the urban spectrum in Northern Ireland. While in the city, the public transport patronage is more and is diverse in terms of the age of passengers due to good frequency and availability, outside the city limits it is mostly used by students and free bus pass holders.

'....Transport issues are the most important for the young and the elderly......the young person going to school, public transport is vital to them.... and the older retired person who doesn't want to have a car....' (Male, 67 years, Banbridge)

But while we find that these two segments are more dependent on public transport, their choices are restrained by driving license and car availability or influenced by the free cost of transport option. So it is more of a compulsive option rather than a conscious choice to move towards sustainable transport.

'....No, I don't own a car. That's partly why I get a bus... cause I don't drive. If I had a car I would use it!' (Male, 19 years, Belfast)

Another type of observation was that as public transport did not offer flexibility, it was unsuited for families with young children who had to do trip chaining. Modal shift was also observed in case of family status changing with the arrival of children and associated childcare arrangements.
'....Personally tend to use car, because...... I have a one year old child....so drop off and pick up enroute work..... but if I didn't have that I would use park and ride as the journey would be quicker and also probably be cheaper...' (Male, 34 years, Belfast)

However, a reverse modal shift was observed as well with the free bus pass. One participant commented that his mother had never used the bus before, but with the free bus pass, she would predominantly use the bus now. A modal shift is noted in this demographical segment as after retirement, activities are less time bound and more flexible such that the frequency of public transport services are not perceived as a major deterrent.

Thus, human demography largely constrains the choice of mode in the current study context.

Implementation and acceptance of integrated policy measures

To explore the influence of policy issues in the real world, in terms of implementation of the planning strategies, indepth interviews were conducted with the executives, planners, policy makers, transport providers and other independent experts. The impact of these policies on the local residents was then explored using the focus group discussions in the case study areas to understand the success of these strategies. Most notably the stress was on efforts to improve accessibility using modal split and restraint measures towards the city core. This was implemented using the Park and Ride scheme mainly which is gaining popularity while in the suburbs the focus is on improving the connectivity between housing growth and transportation with emphasis on brownfield regeneration where possible. Also the park and ride system brought in new public transport users who were not using public transport before.

'...I suppose the new thing is the Park and Ride, in Sprucefield.... and so on. And there is probably scope for some more further out.... Like of I was going to Belfast....I would go to Sprucefield..... from home to Sprucefield and get the bus in...' (Male, 53 years, Banbridge)

The availability of free car parking spaces in some parts of the city is visualized as another barrier for these measures as free parking reduces the overall cost of travel by car and the convenience and independence factors further strengthen the preference.

'....The park and ride is only 3 miles away and I get the free parking on the street, so again it wouldn't pay me'. (Female, 29 years, Ballynafeigh, Belfast) 
To increase the uptake of the Park and Ride scheme, especially in the morning rush hours, more dedicated bus lanes have been introduced causing a huge uproar among road users. This was also to facilitate the other big transportation initiative, the Belfast rapid transit which is designed to connect the park and ride sites to the city centre through dedicated bus corridors in the near future. So we find that the government has adopted a 'carrot and stick' approach to change travel behaviour. Also while the focus group participants have reported a generally low acceptance to these constraint measures, the in-depth interviewee's have satisfactorily commented on the success of these schemes. However, this difference of opinion is due to their personal role as users and providers, respectively, to these policy initiatives.

'....See the Park and Ride in Belfast,... nobody wants to use them.... I watched the news. The local news.... they are all empty. Nobody wants to use them......everybody just wants to drive to work'. (Male, 25 years, Lisburn)

As we go further out of the Belfast City core, other initiatives like integrating new developments with transportation initiatives were proposed; however, no great success has been achieved in terms of this integration. One such example was the first eco-village in Northern Ireland-Woodbrooke village in Lisburn which would have been an exemplar of the integrated approach but was abandoned midway due to the economic downturn. Another such initiative to promote brownfield regeneration and link it with the railway in the form of a 'transit oriented development' was mentioned by one of the interviewees who then expressed the uncertainty and drawbacks of the scheme and concluded that implementation of integrated land-use and transportation policies were still in infancy.

Trends within trends

At a glance, from the above discussion, the travel patterns and habits in Northern Ireland exhibit a fairly traditional car-dependent society which is vastly rural in nature with scant belief in the public transport system. However, there is a slow and gradual change in this mental set-up and people and over the years the influence of various policy measures and experiences are shaping new beliefs and habits which are encouraging in the light of sustainability. One such example was given by an interviewee in Banbridge who believed that issues like environmental awareness should be instilled from childhood to change behaviour.

'....I honestly do think that you got to start...get the notion into kids head. When I grew up, it didn't matter if you were drinking and driving.... now kids won't even think about it. My generation still thinks......can I have 1 pint, 2 pints and drive?... My kids wouldn't even think about that!.... You know you wouldn't even touch it if you are going to go behind the wheel...... Just wouldn't.....It's just unacceptable behaviour - it's a behavioural thing'. (Male, 53 years, Banbridge)

This explains the effectiveness of soft policies and awareness programs to change travel behaviour. Also a change in travel habit has been noted in the new generation student which was accomplished by offering choices in the form of tailor-made public transport incentives. Thus, segments need to be identified as the way forward is to provide choices rather than using constraints.

'.....we have products to suit them.... like the Y-Link, for e.g. for till the age of 24 finding acceptance...... but lots of things have changed - it used to be third level students all lived in and around Belfast or Queens and you know... now there is a change..... they are here from Mondays to Fridays and they don't travel back by car. They use PT. Gives us new peaks to deal with...' (Male, 56 years, Belfast)

This observation was echoed by an interviewee who noted the same trends.

'.....one of my son's students in Belfast - he has a

car..... but he uses the bus..... He goes up to Belfast in a bus on a Sunday and comes back to Banbridge on a bus on a Friday'. (Male, 67 years, Banbridge)

This shows that if transport policy is 'tailor-made' to address the specific target group needs, public transport ridership can increase thus successfully achieving modal split for sustainable travel patterns.

\section{Conclusion}

The grounded theory thus highlighted seven overarching categories that influence travel behaviour in Northern Ireland. These factors are not mutually exclusive and have interdependency patterns which we shall discuss in this section to identify the core construct using selective coding which explains the mechanism influencing travel behaviour.

From the seven overarching categories that have been discussed, we can identify two main issues that are highly relevant in the present context. Firstly, the issue of car dependency, and secondly, the issue of residential immobility which are key to the travel patterns in Northern 
Ireland. The reliance on car is almost an inherent part of daily lifestyle without which activity participation becomes difficult and impossible in some cases. Previous studies have confirmed this observation of a car-dominated society in Northern Ireland as well (Bains et al. 2011; Cooper et al. 2001). Spanning over a decade across, both the studies still point at Belfast as the most car-dependent city in UK and despite this from the policy standpoint budgetary allocations for investment in roads is four times that of public transport investment (Strategic Investment Board NI 2012). Other studies have also mentioned such disproportionate investment in road infrastructure that resulted in a surge of road traffic as opposed to other sustainable modes (Alam et al. 2013). From our study, we find that car dependency becomes more acute as we go further out of the city. One reason mentioned for this was that Northern Ireland has an overgenerous road share, that is more miles per capita and a lot of those miles are rural roads. Thus, the urban sprawl was generously complimented with road network which acted as a car enabler.

Addressing the next issue of residential immobility, we find that the legacy of the 'troubles' in Northern Ireland played a major role in shaping people's perception of urban form and travel behaviour. The outmigration was a consequence of the perception towards urban form while the car dependency was associated with individual safety and independence. Also the resultant territorial hardening to address safety issues led to a fragmented urban structure and polarization and the outmigration meant the loss of critical mass needed to support a good public transport network. Thus, although self-selection of residential location and travel patterns were the observed outcome, this self-selection was not made under circumstances where there were other equally attractive choices. As people felt safe within their own community, be it in the city or outside, a sense of residential immobility was instilled in the individuals, which is still very dominant all across Northern Ireland today. Again this residential immobility was facilitated by the geography of Northern Ireland as most places were still within commute range. Coupled with this was an over-generous road network, which enabled rural living due to good connectivity, thus further strengthening the anti-urban sentiments. The result is a reciprocal relationship between car dependency and residential mobility translating into the current travel patterns.

The geographical size and extent of Northern Ireland, which acts as the backdrop to this pattern also plays a crucial role as travel to most parts, are still within easy daily commute range. Again this spatial context plays a unique role in terms of mode choice. While on the macrolevel, it acts as a car enabler, and on a micro-level, it acts as a barrier to a good public transport network. This is because of the topography of Belfast coupled with the territorial hardening which resulted in a radial structure of public transport network. This observation was made by many participants who commented on the ease of access to the city centre but the difficulty to go to another part of the city which resulted in longer journey times using public transport.

Finally, government policies have also played a great role in shaping these patterns, in particular land-use policies. Between 1971 and 1981, Belfast experienced a massive outmigration and intense decentralization resulting in creation of a weak city centre in terms of an employment hub as jobs were more dispersed towards south of the city centre which offered greater free parking availability (McEldowney et al. 2003, 2005). Coupled with this, since the 1960s, planning attempted to limit the urban sprawl to preserve the surrounding hills and the Lagan Valley from urban encroachment and the outer satellite towns in the regional hinterland were designated to accommodate the overspill and meet the new demands (Boal 1996). Thus, the creation of dormitory settlements led to the segregation of homes from workplaces, retail and schools coupled by high car ownership have created dispersed patterns of growths and increased commute distances. This led to the loss of the critical mass in the city and to attract new developments and investors after the decline in business due to the troubles, high car parking provision standards in the Belfast city centre was made available (McEldowney et al. 2005). Thus, this fivefold increase in parking provisions within the city centre further aggravated the situation (Shuttleworth et al. 2000). Thus, out of city living alternatives and easy commute facility with free parking led to both residential immobility and car dependency. Most of the interviewees and some of the Lisburn and Banbridge focus group participants exhibited this pattern of out of city residential location and car commute to work and have expressed satisfaction with this arrangement. One participant commented on the decentralization of the government offices as well in the periphery of the city which makes it difficult to access by public transport and compounded with it car is a necessity to attend meeting or visit other places on official duty from these decentralized locations. Thus, while centralization is the key to the success of public transport network, decentralization is still in practice.

A stress on the implications of these government policy measures was indicated in the in-depth interviews. In particular, two broad approaches were mentioned that have been adopted by the government to tackle the issue of car dependency and residential location. Firstly, towards the city core, the use of restraint policies like introducing bus lanes and taking away motor lanes have been implemented and are complemented by park and ride facilities along the periphery of the city to achieve modal split. Secondly, as we go further away from the city limits, the policies are 
more focussed on integrating the housing with transportation linkages with an overall brownfield regeneration objective where possible. Also policies aimed at promoting active travel have been identified in the form of footbridges to connect parts of the town in places like Banbridge. Then, there are the soft policies which are aimed at changing behaviour in the form of travel plans, cycling and walking to school, etc. Thus, a 'carrot and stick' approach is being adopted but resistance to these measures have also been observed among the residents showing an initial low level of acceptance.

Also while respondents have mentioned family, friends and familiarity with the area as reasons for choosing to live there creating residential immobility, the emergence of 'commuter towns' and the rapid increase in the population of these commuter towns show that urban form amenities and facilities also play an important role. The commuter towns are generally located for easy commute along motorways and again people choose these commuter towns to stay close to their family but still within a mass location to enjoy better infrastructure. Thus, urban infrastructure accessibility is of prime importance to the residents offered by these new developments along with the affordability perspective. Also these changing patterns of settlements and travel behaviour is encouraging to find as while there is a strong anti-urban sentiment, the growth of commuter towns is essentially a creation of mass location. The flexibility in travel patterns due to the rigidity of residential location along with the growth of commuter towns which are essentially mass locations thus provides just the right mix for public transport patronage. However, this needs to be complimented with mass destination location for jobs as well for which further land-use intervention is required to achieve sustainable travel patterns.

We find that on the overall, land use has played a dominant role in shaping the travel patterns in the past and is continuing to do so. This has translated in the form of car dependency and residential immobility over the years in Northern Ireland. However, current policies are now more focussed at achieving the modal split and curbing the sprawl by brownfield regeneration initiatives. Studies from other parts of UK have also mentioned the effectiveness of landuse policy in reducing car usage (Aditjandra et al. 2012). Also soft policy measures are being introduced to increase awareness on travel alternatives and environmental issues and have already started to show results in the form of change in travel habits in the younger generation. Also more research is needed in the local context to explore the choices that need to be provided as literature has stressed on the effectiveness of providing choices rather than trying to change behaviour (Handy 1996). One such key avenue for further research would be to explore the 'latent' alternatives to travel patterns which could have been a possibility to understand the barriers to its implementation. The same needs to be evaluated in terms of residential location options to identify the contesting alternatives and barriers to these choices. These are vital to offer attractive choices for a sustainable future and for policy to adapt measures which are more attractive to the masses.

Lastly, this study aimed at exploring the interrelationship patterns among factors influencing travel behaviour in the local context to understand the mechanism of these relationships with evidence-based explanation. However, to inform policy, the rigor of quantitative analysis is required to compliment this study for theory proposition. Thus, while the results from this study highlight the main factors influencing travel behaviour, the magnitude of these interrelationships can only be determined using quantitative research. This would lend predictive validity to these results and shall be sample representative of the whole of Northern Ireland for generalizability and to inform policy.

Acknowledgments The findings presented in this paper forms part of a doctoral research sponsored by the University of Ulster, Jordanstown, UK. The authors would like to thank all the participants and experts for their invaluable time and comments to further strengthen the dialogue between land use and transport in the Northern Ireland context. And finally the authors would like to thank the two anonymous reviewers for their invaluable comments.

\section{References}

Aditjandra PT (2013) The impact of urban development patterns on travel behaviour: lessons learned from a British metropolitan region using macro-analysis and micro-analysis in addressing the sustainability agenda. Res Transp Bus Manag 7:69-80

Aditjandra PT, Mulley C, Nelson JD (2009) Neighbourhood design impact on travel behavior: a comparison of US and UK experience. Projections 9:28-56

Aditjandra PT, Cao X, Mulley C (2012) Understanding neighbourhood design impact on travel behaviour: an application of structural equations model to a British metropolitan data. Transp Res Part A: Policy Pract 46(1):22-32

Aditjandra PT, Mulley C, Nelson JD (2013) The influence of neighbourhood design on travel behaviour: empirical evidence from North East England. Transp Policy 26:54-65

Alam JB, Wadud Z, Alam JB, Polak JW (2013) Energy demand and economic consequences of transport policy. Int J Environ Sci Technol 10:1075-1082

Allan G (2003) A critique of using grounded theory as a research method. Electron J Bus Res Methods 2(1):1-10

Antipova A, Wang F, Wilmot C (2011) Urban land uses, sociodemographic attributes and commuting: a multilevel modeling approach. Appl Geogr 31(3):1010-1018

Bains G, Ridley A, Carrarini A, Craig S (2011) Car dependency scorecard 2011: the top European cities for sustainable transport. Campaign for Better Transport, London

Banister D (1996) Energy, quality of life and the environment: the role of transport. Transp Rev 16(1):23-35

Banister D (2007) Land use, planning and infrastructure issues in transport, commissioned paper for the shadow committee on climate change. Transport Studies Unit, Oxford 
Banister D (2008) The sustainable mobility paradigm. Transp Policy 15(2):73-80

Boal FW (1996) Integration and division: sharing and segregating in Belfast. Plan Pract Res 11(2):151-158

Bohte W, Maat K, van Wee B (2009) Measuring attitudes in research on residential self-selection and travel behaviour: a review of theories and empirical research. Transp Rev 29(3):325-357

Cao X, Mokhtarian PL, Handy SL (2009) Examining the impacts of residential self-selection on travel behaviour; a focus on empirical findings. Transp Rev 29(3):359-395

Clifton KJ, Handy S (2003) Qualitative methods in travel behaviour research. In: Jones D, Stopher P (eds) Transport survey quality and innovation. Elsevier, Oxford, pp 283-302

Cooper J, Ryley T, Smyth A (2001) Contemporary lifestyles and the implications for sustainable development policy: lessons from the UK's most car dependent city, Belfast. Cities 18(2):103-113

Crane R, Crepeau R (1998) Does neighborhood design influence travel? A behavioral analysis of travel diary and GIS data. Transp Res Part D Transp Environ 3(4):225-238

Department for Regional Development (2010) Regional development strategy 2035: building a better future. DRDNI, Belfast

Department of Energy and Climate Change (2013) Energy consumption in the UK (2013). Department of Energy and Climate Change, UK

Dey I (2004) Grounded theory. In: Seale C, Gobo G, Gubrium JF, Silverman D (eds) Qualitative research practice. Sage, London, pp 80-94

Dur F, Yigitcanlar Y (2014) Assessing land-use and transport integration via a spatial composite indexing model. Int J Environ Sci Technol. doi:10.1007/s13762-013-0476-9

Gardner B, Abraham C (2007) What drives car use? A grounded theory analysis of commuters' reasons for driving. Transp Res Part F Traffic Psychol Behav 10(3):187-200

Glaser BG (1992) Basics of grounded theory analysis. Sociology Press, Mill Valley

Gordon I (2008) Density and the built environment. Energy Policy 36(12):4652-4656

Handy S (1996) Methodologies for exploring the link between urban form and travel behavior. Transp Res Part D Transp Environ 1(2):151-165

Headicar P (2003) The contribution of land use planning to reducing traffic growth: the English experience. EJTIR 3(2):137-154

Hickman R, Banister D (2007) Transport and reduced energy consumption: what role can urban planning play? Working paper no. 1026 edn, University of Oxford

Kitamura R, Mokhtarian PL, Laidet L (1997) A micro-analysis of land use and travel in five neighborhoods in the San Francisco Bay Area. Transportation 24:125-158

Leck E (2006) The impact of urban form on travel behavior: a meta analysis. Berkeley Plan J 19:37-58

Maat K, van Wee B, Stead D (2005) Land use and travel behaviour: expected effects from the perspective of utility theory and activity-based theories. Environ Plan 32(1):33-46

McEldowney M, Scott M, Smyth A (2003) Integrating land-use planning and transportation-policy formulation in the Belfast Metropolitan area. Irish Geogr 36(2):112-126

McEldowney M, Ryley T, Scott M, Smyth A (2005) Urban Form and reducing the demand for car travel: towards an integrated policy agenda for the Belfast Metropolitan Area? In: Renewing urban communities Ashgate, Aldershot, Hampshire, England, pp 75-93

Naess P (2003) Urban structures and travel behaviour. Experiences from empirical research in Norway and Denmark. EJTIR 3(2):155-178

Naess P (2011) 'New urbanism' or metropolitan-level centralization? A comparison of the influences of metropolitan-level and neighborhood-level urban form characteristics on travel behavior. J Transp Land Use 4(1):25-44

NINIS (2011) Northern Ireland level information. NISRA, NI

Schwanen T, Dieleman FM, Dijst M (2001) Travel behaviour in Dutch monocentric and policentric urban systems. J Transp Geogr 9(3):173-186

Shuttleworth I, Power J, McKinstry D (2000) Examining 1991 travelto-work patterns in the Belfast Urban Area as a context for urban employment policy. Appl Geogr 20(2):177-202

Simma A, Axhausen KW (2003) Interaction between travel behaviour, accessibility and personal characteristics: the case of upper Austria. EJTIR 3(2):179-197

Snellen D, Borgers A, Timmermans H (2002) Urban form, road network type, and mode choice for frequently conducted activities: a multilevel analysis using quasi-experimental design data. Environ Plan A 34(7):1207-1220

Stead D (2001) Relationships between land use, socioeconomic factors, and travel patterns in Britain. Environ Plan 28(4):499-528

Strategic Investment Board NI (2012) Investment Strategy for Northern Ireland 2011-2021. Northern Ireland Executive, Belfast

Strauss A, Corbin J (1998) Basics of qualitative research: techniques and procedures for developing grounded theory, 2nd edn. Sage Publications, Thousand Oaks

Susilo YO, Maat K (2007) The influence of built environment to the trends in commuting journeys in the Netherlands. Transportation 34(5):589-609

Susilo YO, Williams K, Lindsay M, Dair C (2012) The influence of individuals' environmental attitudes and urban design features on their travel patterns in sustainable neighborhoods in the UK. Transp Res Part D Transp Environ 17(3):190-200

The Planning Service November 2004, Belfast Metropolitan Area Plan Draft Plan, The Department of the Environment (DOE), NI

Timmermans H, van der Waerden P, Alves M, Polak J, Ellis S, Harvey AS, Kurose S, Zandee R (2003) Spatial context and the complexity of daily travel patterns: an international comparison. J Transp Geogr 11(1):37-46

van de Kaa EJ (2010) Prospect theory and choice behaviour strategies: review and synthesis of concepts from social and transport sciences. EJTIR 10(4):299-329

Walker D, Myrick F (2006) Grounded theory: an exploration of process and procedure. Qual Health Res 16(4):547-559

World Commission on Environment and Development (1987) Our common future. Oxford University Press, Oxford

Yigitcanlar Y, Teriman S (2014) Rethinking sustainable urban development: towards an integrated planning and development process. Int J Environ Sci Technol. doi:10.1007/s13762-0130491-x 